\title{
Corrigendum
}

\section{Reappraising the long-term course and outcome of psychotic disorders: the AESOP-10 study - CORRIGENDUM}

\author{
C. Morgan, J. Lappin, M. Heslin, K. Donoghue, B. Lomas, U. Reininghaus, A. Onyejiaka, \\ T. Croudace, P. B. Jones, R. M. Murray, P. Fearon, G. A. Doody and P. Dazzan \\ doi:10.1017/S0033291714000282. Published online by Cambridge University Press, 26 February 2014.
}

The authors would like to amend an incorrect citation found on page 2 of the above article (Morgan et al. 2014). The citation to Jaaskelainen et al. 2008, should instead be to Jääskeläinen et al. 2013.

The full reference to the citation is:

Jääskeläinen E, Juola P, Hirvonen N, McGrath JJ, Saha S, Isohanni M, Veijola J, Miettunen J (2013). A systematic review and meta-analysis of recovery in schizophrenia. Schizophrenia Bulletin 39, 1296-1306.

\section{Reference}

Morgan C, Lappin J, Heslin M, Donoghue K, Lomas B, Reininghaus U, Onyejiaka A, Croudace T, Jones PB, Murray RM, Fearon P, Doody GA, Dazzan P (2014). Reappraising the long-term course and outcome of psychotic disorders: the AESOP-10 study. Psychological Medicine. Published online 26 February 2014. doi:10.1017/ S0033291714000282. 